\title{
A Philosophical Orientation: Judges Decision for Good Faith Land Sale and Purchase Cases in Indonesia
}

\author{
Albertus Usada $^{1}$, I Gusti Ayu Ketut Rachmi Handayani², Lego Karjoko ${ }^{3}$ \\ ${ }^{1.2 .3}$ Universitas Sebelas Maret \\ Surakarta, Indonesia \\ albert.usada19@student.uns.ac.id
}

\begin{abstract}
This paper aims to find out the basic orientation of the judges in adjudicating good faith in land sale and purchase cases as a "ratio decidendi" in their decisions. The reason and consideration related to the context of the flow of legal discovery as a framework or paradigm of the Judges from the Judge's legal reasoning in constructing his decision against a concrete case of good faith land sale and purchase cases. This study used the normative legal method to analyze the research problem. The researchers involved three approaches: statutory, conceptual, and case approach. The results show that the philosophical decision of the Judges has orientation. The Judges applied the ontological, the axiological, and the epistemological basis based on the legal ideals of Pancasila, specifically in the first, second, and fifth precepts. Furthermore, there are three streams of philosophical orientation of the judges in adjudicating and deciding good faith cases in land sale and purchase. The streams included the "legisme" orientation, which determines based on positive Law, the orientation of "begriffsjurisprudenz", which decides based on a new situation as new understandings according to the legal system, and the orientation of "interessenjurisprudenz" which decides based on interests and needs according to their objectives.
\end{abstract}

Keywords- Judges, Good Faith, Land Sales and Purchase, Legal Findings, Philosophical Orientation.

\section{INTRODUCTION}

Legal development has three main components from the legal system that involves substance, structure, or culture [1]. Those components run in legal reform that considers the applied plural legal order and globalization that brings influence. Fence M Wantu stated that the condition is efforts to increase certainty, awareness, service, and law enforcement with the core of justice, truth, order, and welfare [2].

Constitutions of the Republic of Indonesia 1945, "Article 24 (1) stated, the judicial power shall be independent and shall possess the power to organize the judicature in order to enforce law and justice." The Article emphasized Indonesia as a Legal State. The sake of justice based on God Almighty carried out from the trial [3]. The State Court applies and enforces Law and authority based on Pancasila [4].

Between legal development and association and legal order institutions and the influence of globalization, legal disputes in the civil sector are increasingly diverse and complex in line with the need for land. In the sale and purchase of land, disputes over ownership rights often arise between the original owner of the land and the good faith buyer. Ridwan Khairandy, as cited in Martin Hesselink, identified good faith [5] as an abstract understanding. It requires legal interpretation for applying good faith by the Judge in terms of the Judge's authority to intervene in contractual obligations based on the principle of good faith [6]. Honesty, directness, and loyalty reflect in good faith. Good faith requires attention to the interests of others [7], and on the other side, good faith defines as the gateway for moral values in Law [8]. If the buyer is granted a good faith buyer in lawsuit argument, he will be considered the next owner, even though an ineligible party carries out the land sale [9]. However, suppose the buyer's argument in good faith is rejected, the transfer of rights to his land as the object of sale and purchase is considered invalid. The original owner remains the legal owner of the land [10].

The position of the good faith principle is significant regarding the process of buying and purchasing land rights. All must be based on good faith before the parties move towards a sale and purchase agreement. In transfering land rights, both parties required good faith. The land sale and purchase agreement will undoubtedly result in a legal dispute that can harm one of the parties themselves if the good faith principle is neglected. The good faith principle concerning buying and selling in the normative realm provides legal protection for good faith buyers. In practice, how good faith buyers obtain legal protection becomes relevant as a legal issue [11].

Several problems mentioned above illustrate the gap in implementing the Law of the agreement in land rights sale and purchase as a legal issue. The gap shows the legal interests of the disputants who face each other between the previous owner of the land and the good faith buyer in the legal dispute of land ownership rights in the district court.

The emergence of the dispute over land ownership rights is normative, starting from regulating the good faith principle $\mathrm{h}$ in "Article 1338 paragraph (1) of the Civil Code", which has abstract formulation and requires further interpretation. In judicial practice, Judges figure out a philosophical orientation in a good faith in land 
sale and purchase decision, which is connected with the theory of legal discovery and the idea of the "ratio decidendi" as reason and consideration based on legal interpretation and reasoning.

Thus, the main problem of this legal research is how the judges' philosophical orientation in the decision of good faith land sale and purchase cases. The answer to the problem formulation is relevant to recognize the philosophical orientation of judges who adjudicate good faith land sale and purchase cases. The philosophical orientation is recognized as reasons and considerations or the Judge's "ratio decidendi". It is related to the context of the legal discovery as thought or paradigm of judges based on legal reasoning in constructing its decision on a concrete case of a good faith case in the land sale and purchase.

\section{RESEARCH METHOD}

This study used normative legal research [12] or doctrinal research, which provides descriptive analysis with three approaches [13]; first, the statutory approach[14]. This approach used to analyze the Law related to good faith governance as the legal basis in "Article 1338 (3) of Civil Code", and the management in "Basic Agrarian Law (Law Number 5,1960)" as well as its regulation in implementing the regulation of land rights as the object of an agreement in sale and purchase cases. The second is the conceptual approach [15]. This approach is connected with the concept of good-faith as the legal principle "bona fides, te goeder trouw beginsel, good faith principle" and "nemo plus iuris transferre (ad alium) potest quam ipse habet" doctrine. It means a person does not have the right to transfer anything more than what he has, as well as the opinion of legal experts on the principle of Agood faith concerning the meaning of a good-faith buyer. The third approach is the case approach [16]. This approach concerns to various decisions of district courts, high courts and the Supreme Court, and the Jurisprudence of the Supreme Court from 1955-2021 as primary legal material about the Judges' "ratio decidendi" and the rule of Law concerning good faith in judicial practice and the classification of court decisions and the criteria for the meaning of a good-faith buyer in civil disputes over the land sale and purchase. This research collected the data using literature studies which further analyzed in deductive syllogism and interpretation. The philosophy of Pancasila becomes a major premise [17], while the reasons and legal considerations of the Judge as the "ratio decidendi" in adjudicating good faith cases in the land sale and purchase is a minor premise.

\section{FINDINGS AND DISCUSSION}

\section{The Pancasila Philosophy and Legal Ideals}

Pancasila is a philosophical system that shows the essence of meaning stratified into five precepts that form a pyramid [18]. The conception of Pancasila here is relevant to the implementation of constitutional power as an autonomous state authority to administer justice within the comprehensive judiciary in order to execute Law and justice based on Pancasila and the 1945 Constitution of the Republic of Indonesia. Sudjito Atmoredjo discusses the status of Pancasila as the basis of State and as the origin of all sources of Indonesian Law. The Constitution of the Republic of Indonesia in 1945 has formed an important message in the State's essential and objectives [19]. The primary and objectives of the State are arranged in the settlement of the Republic of Indonesia. The formation is sovereign by the people based on Pancasila [20].

Pancasila is the source from all beginnings of Law that is practiced in Indonesia. The sources of relevant law must not differ with Pancasila. As a source of all sources of Law, Pancasila is the beginning of legal order, which includes a sense of life, awareness, legal and moral values that cover a psychological characteristic and the character of the Indonesian [21].

Pancasila has a constitutional function that determines the legal system of Indonesian State and has a regulatory function of positive Law that applies in Indonesia. In the legal field, the manifestation of the Pancasila ideology as the basis of the State is the ideal of Pancasila law, which functions as the foundation, guideline, and direction of development and development of national Law. The results of the seminar on Meeting the Ideals of Law and the Application of National Legal Principles formulated that the ideals of Law ("rechtsidee") contain the meaning of the nature of Law as a rule of community behavior which is rooted in ideas, feelings, intentions, creativity, and thoughts of the community itself [22]. Pancasila as a legal ideal is used as the bridge that will bring the Indonesian people to the ideas they aspire to [23].

\section{The Good faith and Good-faith Buyer Definition in Land Sale and Purchase}

A literature study classified good faith into two, those are subjective good faith and objective good faith. Within land rights sale and purchase, subjective good faith is defined as a buyer's honesty who is entirely unaware of any defects in the sale and purchase of the land. Objective good faith is interpreted as propriety for buyers who are in line with the general view of society.

Furthermore, the doctrine of good faith buyers whom Law protects is arising. According to Subekti, a good-faith buyer is a buyer who does not know that he is dealing with a person who is not the owner [24]. Ridwan Khairandhy explained that a good-faith buyer buys goods with complete confidence that the seller owns the goods he sells [25]. Agus Yudha Hernoko explained that a good-faith buyer is honest and does not know the drawbacks of buying goods [26].

Jaap Hijma, a professor at Leiden University, explained the regulation of the good faith principle in the new Dutch Civil Code, "Nieuw Burgerlijk Wetboek," NBW (The Netherlands New Civil Code) concerning "open criteria" and the role of judges in judicial considerations as a new trend. Jaap Hijma 
mentions the "open criteria" as "good faith and fair dealing," which is formulated in the phrase "reasonableness and fairness" whose arrangements are not only regulated in contract law, but are also regulated in engagement law and become part of property law [27].

In Indonesia, good faith is not explained in the legislation as positive Law. In the context of the land sale and purchase agreement, the basis for the regulation of good faith as a legal principle is stated in "Article 1338 paragraph (3) of the Civil Code", stipulating that every agreement must be carried out in good faith. According to Kartini Muljadi, the parties who bind themselves in an agreement approved the contract, then the implementation of achievements in the agreement must be fully respected, following the parties' wishes at the time the agreement is closed [28]. The meaning of the agreement includes a sale and purchase agreement of land rights as the basis for the transfer of ownership of land rights. However, the provisions of "Article 1338 paragraph (3) of the Civil Code" do not determine the meaning of good faith. The legal meaning of good faith is still abstract so that if there is a civil law dispute, the interpretation of good faith is left to the Judge's authority in judicial practice.

\section{Philosophical Orientation of Judges and Legal Findings on the Interpretation Development of Good- Faith Buyers in Judicial Practices in Indonesia}

The philosophical orientation of judges who adjudicate cases of good faith in the sale and purchase of land is the basis of reasoning and evidence or "ratio decidendi" in their decisions. It also stands as a framework of thought or paradigm of the judges based on legal reasoning in constructing their decisions [29] on a concrete case of good faith in buying and selling land.

In his decision, the Judge's Philosophical Orientation contains 3 (three) dimensions: ontological, axiological, and epistemological. First, the ontological dimension relates to the nature of Law. This dimension is defined as the principle of justice and truth, or as the meaning of the Law itself. Then, the nature of Law as a positive legal norm in a statutory or legal system is designated as social behavior. Second, the axiological dimension relates to the objectives of the Law, which are defined as justice, legal certainty, and expediency. Third, the epistemological dimension relates to the approach used to the subject and object of consideration based on legal reasoning with a ratio, senses, and intuition [30]. Then, the meaning of legal discovery is the process of concretizing general legal regulations ("das sollen") by paying attention to certain concrete events (“das sein") [31].

The philosophical orientation of the judges who adjudicate cases of good faith in the sale and purchase of land can be categorized into the various orientation of their schools of thought, namely "legisme, begriffsjurisprudenz, and interessenjurisprudenz” [32].
"Legisme" orientation relies on all laws made by the authorities' instructions as legislators and the Law alone as a source of Law for all legal issues. Judges are obliged to implement the Law to concrete events through grammatical interpretation [33]. "Begriffsjurusprudenz" orientation places judges to play an active role in implementing a law with new circumstances and giving a role to the habits and values that live in society as a source of Law [34]. The "Interessenjurisprudenz" orientation places judges on an orientation that relies on the purpose of the Law being made or a legal regulation that is not merely formal-logical, but must be assessed according to its purpose to answer conflicts between interests. According to this orientation, the Law is seen as a result of conflicting interests as a legal dispute. This "interessenjurisprudenz" orientation is a reaction to the "begriffsjurisprudenz" orientation [35].

Based on the legal interpretation development on the meaning of good faith as a legal principle and good-faith buyers in judicial practice in Indonesia, based on various court decisions and the Indonesian Supreme Court (MA) from 1955-2021, five categories of philosophical orientation were obtained. In the sale and purchase of land that produces legal rules, criteria for buyers in good faith and objective legal protection are as follows:

First, a god-faith buyer is a buyer who never suspects that the person selling an object is the person who has the right to sell the object [36]. A Good-faith buyer is a buyer who is not aware of any legal defects in buying and selling. [37]. Second, in buying and selling that has fulfilled the conditions determined by law, the buyer is considered to have good faith [38]. A good-faith buyer defines as a buyer who does not know there is an error in the buying and selling process [39]. Third, the buyer will be considered to be in good faith when buying a disputed object that has been certified before the Land Deed Making Officer (PPAT) [40]. Fourth, a buyer is recognized as a good-faith buyer when the sale and purchase of land can be legally proven through authentic evidence regarding previous land ownership [41]. Fifth, buyers have good intentions through auctions, namely when there are minutes of auctions affixed with the initial decision that can be executed [42]. The buyer is considered in good faith if the land was obtained from the state auction office along with the ownership documents [43].

Theoretically, the legal rules that determine the criteria for good-faith buyers and objective legal protection through the Supreme Court's decision are the "ratio decidendi" of the Judge's decision as to the reasons and legal considerations that form the basis of the reason [44] for the decision [45]. Michael Zamder defined "ratio decidendi" as "a proposition of law which decides the case, in the light or the context of the material facts" [46]. The construction of the "ratio deciendi" of the judges' decisions according to the jurisprudence of the Supreme Court toward good-faith buyers with land objects includes two contextual components, i.e., the context of legal reasoning and the context of legal discovery ("rechtsvinding"). 
Five categories of the philosophical orientation of the judges show that the philosophy of Pancasila is the philosophical basis for judges through their legal decisions. As the highest state court in Indonesia, the Supreme Court has confirmed that Pancasila is the source of the Law. The Judges' philosophical orientation comes from the first principle of Pancasila, whose spiritual power is reflected in the origin of the Judge's decision "For Justice based on God Almighty," and always based on the second precepts of Pancasila within the framework of obtaining legal goals as the fifth precepts of Social Justice for all Indonesian people.

Based on the legal principles of various Supreme Court decisions that have become Permanent Jurisprudence, then further elaboration as a guide for judges is implementing the Chamber System at the Supreme Court since 2011 and effective gradually from 2012 until now. The Supreme Court has provided guidelines for all judges who handle cases similar to or similar to previous cases that have been decided and have permanent legal force as part of the Jurisprudence Law. The aim is to provide unity in applying Law (uniformity) and consistency of decisions.

"The Supreme Court Circular Letter (SEMA) Number 4 of 2016" in part of "General Civil" as a result of the Agreement of the Plenary Meeting of the Civil Chamber" has formulated criteria for buyers in good faith to provide justice, legal certainty, and benefits for buyers with good intentions of legal land objects. It is a form of Legal protection against good-faith buyers as land objects in the perspective of Pancasila philosophy and as a concrete way of the good-faith principle. It is referred to the provisions of "Article 1338 paragraph (3) of the Civil Code", and the concrete way of the principle of "pacta sunt servanda" as referred to in the provisions "Article 1338 paragraph (1) of the Civil Code", which is subject to certain conditions, as follows [47]:

a. Conducting the sale and purchase of the land object with legal procedures and documents as determined by the laws and regulations, namely:

- The purchase of land through public auction; or

- The purchase of land before the Land Deed Making Officer (by the provisions of "Government Regulation Number 24, 1997 concerning Land Registration"); or

- The purchase of customary/unregistered land which is carried out according to the provisions of the customary Law:

- The carried out in cash and open (in front of/known by the local village head);

- The preceded by research on the land status as an object of the sale and purchase and based on research shows that the land of the object of sale and purchase belongs to the seller;

- The purchases are made at a reasonable price.

b. To execute prudence by examining matters relating to the object of the land being agreed upon, including:
- a seller is someone who has the right to land, which is the object of sale and purchase, following the proof of ownership; or

- The land/object being traded is not in confiscated status; or

- The land/object being traded is not in the status of collateral/encumbrance; or

- For certified land, it has obtained information from the National Land Agency and a history of legal relations between the land and the certificate holder.

Thus, the Indonesian Judicial System, which is an adherent of the Continental European legal system (Civil Law), is in the process of building a unified application of Law (uniformity) so that in judicial practice in Indonesia it produces decisions that are consistent or regular and constant (steady) so that a sense of justice and the legal certainty and legal benefits can be realized.

\section{CONCLUSION}

This study concludes that the Judge's philosophical orientation in his decision to adjudicate good faith cases in the sale and purchase of land has an ontological, an axiological, and an epistemological basis based on the ideals of Pancasila law, specifically the first, the second, and the fifth precepts. To sum up, there are three streams of various philosophical orientation of judges in adjudicating and deciding cases of good faith in the sale and purchase of land, namely the "legisme" orientation, which decides based on positive Law. Then, "begriffsjurisprudenz" orientation based on a new situation as new meanings according to the legal system and jurisprudence and "interessenjurisprudenz" orientation that decides based on legal interests and needs according to its objectives.

\section{REFERENCES}

[1] M. Roestamy, "Model Land Supply for Land Bank to House Application Martin," Bestuur, vol. 7, no. 2, 2019.

[2] A. Jumari, "Potensi Pelanggaran Pengelolaan Limbah Bahan Berbahaya dan Beracun," J. Best., vol. 7, no. 2, 2019.

[3] Yusriando, "Konstruksi Sistem Jaminan Sosial Nasional Bidang Kesehatan Yusriando," Bestuur, vol. 7, no. 2, 2019.

[4] U. K. Mishra and A. Negi, "Transgender and the Right to Employment in India: Analysing the Trajectories of Discrimination," Bestuur, vol. 9, no. 1, pp. 34-43, 2021.

[5] L. C. Lintang, Adriano Martufi, and J.W. Ouwerker, "The Alternative Concepts of Blasphemy Law in Indonesia: Legal Comparison with Ireland and Canada," Bestuur, vol. 8, no. 2, pp. 121-128, 2020.

[6] S. R. Novikasari, D. Q. Ly, and K. Gershaneck, "Taxing Micro, Small and Medium Enterprises in Yogyakarta: Regulation and Compliance," Bestuur, vol. 9, no. 1, 2021.

[7] M. A. Mohd Sani and D. D. Abdul Hamed Shah, "Freedom of Religious Expression in Malaysia," $J$. 
Int. Stud., pp. 33-50, 2020.

[8] S. A. Estikomah, "Aspek Hukum Import Sampah Plastik," Bestuur, vol. 7, no. 2, p. 41, 2019.

[9] A. A. Hamzana, "Pelaksanaan Standarisasi Pelayanan Pariwisata Halal dalam Pengembangan Pariwisata di Nusa Tenggara Barat," Pena Justisia Media Komun. dan Kaji. Huk., vol. 17, no. 2, pp. 1-16, 2018.

[10] B. Prasetyo, I. G. A. K. R. Handayani, A. Sulistyono, and L. Karjoko, "Legal framework for social security state civil apparatus," Int. J. Adv. Sci. Technol., vol. 28, no. 20, pp. 310-313, 2019.

[11] I. Gusti Ayu Ketut Rachmi Handayani, G. Gunarto, A. Mashdurohatun, I. Gusti Putu Diva Awatara, and F. U. Najicha, "Politic of legislation in Indonesia about forestry and the mining activity permit in the forest area of environmental justice," Journal of Engineering and Applied Sciences, vol. 13, no. 6. pp. 1430-1435, 2018.

[12] A. K. Jaelani, I. G. A. K. R. Handayani, and L. Karjoko, "Development of tourism based on geographic indication towards to welfare state," Int. J. Adv. Sci. Technol., vol. 29, no. 3 Special Issue, pp. 1227-1234, 2020.

[13] R. D. Luthviati, "The Role of Local Governments in the Defense of Leading Products Resti," J. Best., vol. 8, no. 2, pp. 121-128, 2020.

[14] Yuliandri, G. A. K. R. Handayani, T. Prasetyo, K. Seregig, and H. Tegnan, "Retributive justice theory and the application of the principle of sentencing proportionality in Indonesia," J. Leg. Ethical Regul. Issues, vol. 21, no. 4, pp. 1-8, 2018.

[15] I. G. A. K. R. Handayani, H. Glaser, S. Monteiro, E. D. Kusumawati, A. K. Jaelani, and F. U. Najicha, "Water availability in the framework of environmental justice: reconstruction of municipal waterworks (pdam) regulations," Int. J. Business, Econ. Law, Vol. 20, Issue 4 2019, vol. 20, no. 4, pp. 51-55, 2019.

[16] I. Iswantoro, "Strategy and Management of Dispute Resolution, Land Conflicts at the Land Office of Sleman Regency," J. Hum. Rights, Cult. Leg. Syst., vol. 1, no. 1, pp. 1-17, 2021.

[17] A. Ma, "Legal Aspects of Environment in Indonesia: an Efforts to Prevent Environmental Damage and Pollution," J. Hum. Rights, Cult. Leg. Syst., vol. 1, no. 1, pp. 18-30, 2021.

[18] A. K. Jaelani and R. D. Luthviati, "The Crime Of Damage After the Constitutional Court's Decision Number 76 / PUU-XV / 2017," J. Hum. Rights, Cult. Leg. Syst., vol. 1, no. 1, pp. 31-41, 2021.

[19] R. Res, "Implementation of Parate Executie Object of Liability Juridical Overview of Mortgage," $J$. Hum. Rights, Cult. Leg. Syst., vol. 1, no. 1, pp. 4253, 2021.

[20] Syahlan, "Effective and Efficient Synchronization in Harmonization of Regulations Indonesia," J. Hum. Rights, Cult. Leg. Syst., vol. 1, no. 1, pp. 54-70, 2021.

[21] R. I. Ichlas, "Questioning the Independence of Media Coverage in the 2019 Elections," J. Best., vol.
8, no. 1, 2020.

[22] W. N. Hanum, "Setting of Earth Oil Management in Old Wells Based on the Principle Social Justice," Bestuur, vol. 8, no. 2, p. 70, 2020.

[23] K. Intaniasari, "Gross Split Contract Framework Regulation on the Caring for People," Bestuur, vol. 8, no. 2, p. 96, 2020.

[24] F. U. Najicha, "Oil and Natural Gas Management Policy in Realizing Equal Energy in Indonesia," $J$. Hum. Rights, Cult. Leg. Syst., vol. 1, no. 2, pp. 7179, 2021.

[25] S. D. Baranyanan, "Simplification of Law Regulations in Copyright Criminal Act Settlement," J. Hum. Rights, Cult. Leg. Syst., vol. 1, no. 2, pp. 80-91, 2021.

[26] A. Ma'ruf, “Application of Timber Legality Verification System (SVLK) Policy as Ecolabel Implementation in the Indonesian Timber Industry," J. Hum. Rights, Cult. Leg. Syst., vol. 1, no. 2, pp. 92-99, 2021.

[27] A. A. Herman and M. J. Hayat, "Management of High Secondary Education After Regional Government Law," J. Hum. Rights, Cult. Leg. Syst., vol. 1, no. 2, pp. 395-396, 2021.

[28] M. Jamil, "Fiduciary Security Arrangements and Issues in Indonesia," J. Hum. Rights, Cult. Leg. Syst., vol. 1, no. 2, pp. 109-119, 2021.

[29] G. T. Sekotibo, "The Strength of Evidence (Certificate) in Land Rights Disputes According to Government Regulation No. 24 of 1997 Concerning Land Registration," J. Hum. Rights, Cult. Leg. Syst., vol. 1, no. 2, pp. 120-130, 2021.

[30] I. Iswantoro, "Strategy and Management of Dispute Resolution, Land Conflicts at the Land Office of Sleman Regency," J. Hum. Rights, Cult. Leg. Syst., vol. 1, no. 1, pp. 1-17, 2021.

[31] A. Ma, "Legal Aspects of Environment in Indonesia: an Efforts to Prevent Environmental Damage and Pollution," J. Hum. Rights, Cult. Leg. Syst., vol. 1, no. 1, pp. 18-30, 2021.

[32] A. K. Jaelani and R. D. Luthviati, "The Crime Of Damage After the Constitutional Court's Decision Number 76 / PUU-XV / 2017," J. Hum. Rights, Cult. Leg. Syst., vol. 1, no. 1, pp. 31-41, 2021.

[33] R. Res, "Implementation of Parate Executie Object of Liability Juridical Overview of Mortgage," $J$. Hum. Rights, Cult. Leg. Syst., vol. 1, no. 1, pp. 4253, 2021.

[34] Syahlan, "Effective and Efficient Synchronization in Harmonization of Regulations Indonesia," J. Hum. Rights, Cult. Leg. Syst., vol. 1, no. 1, pp. 54-70, 2021. 